\title{
Drilling the Seismogenic Zone of an Erosional Convergent Margin: IODP Costa Rica Seismogenesis Project CRISP
}

\author{
by César R. Ranero, Paola Vannucchi, Roland von Huene \\ and the CRISP proponents
}

doi:10.2204/iodp.sd.s01.29.2007

\section{Introduction}

Interplate subduction zone earthquakes occur in the seismogenic zone, downdip of the transition from stable slip to unstable slip along the plate boundary megathrust. Currently, mineral transformations and fluid migration are thought to govern the stable to unstable slip transition. In the seismogenic zone, subducting clastic material in the subduction channel changes structure and physical properties and releases fluid as it migrates toward the mantle. Where sediment accretion dominates a convergent margin, the subducted clastic input is trench sediment, and the subducted plate is likened to a conveyor belt traveling from the trench into conditions of elevated temperature and pressure. Trench sediment has been sampled, and the diagenetic and metamorphic changes can be inferred. Moore and Saffer (2001) describe the decrease in porosity and increase in temperature with depth, which results in a transition from opal to quartz, the transformation of clay minerals, cementation by carbonate, zeolites, and quartz, all accompanied by pressure solution. However, where subduction erosion dominates a convergent margin, material input to the seismogenic zone is unknown because it is derived from the base of the upper plate, beyond the sampling capabilities of past scientific ocean drilling (von Huene et al., 2004). Mineral transformations involved in seismogenesis at erosional margins may be very different from those at accretionary margins. Zones of upper plate subduction erosion have never been drilled, nor does geophysics resolve their structure, lithology, and physical properties (Fig. 1). The Japanese riser drill ship Chikyu in the Integrated Ocean Drilling Program (IODP) provides the opportunity to drill the seismogenic zone of an erosional margin and this is the objective of CRISP (Costa RIca Seismogenesis Project).

Subduction erosion along the plate boundary of the Middle America convergent margin: During CRISP the seismogenic zone of the Middle America erosional convergent margin will be sampled and instrumented. A key feature is the unconformable surface across the top of crystalline basement of the upper plate, a regional unconformity imaged in seismic records. Drilling on DSDP Legs 67 (1979) and 84 (1981) revealed that the inferred accretionary prism of Guatemala is instead an extension of the upper plate igneous basement covered unconformably by Eocene to Miocene shallow water sediment. Drill samples from the lower slope contain microfossils that are now more than $3 \mathrm{~km}$ deeper than the water depth in which they lived. Microfossil depth indicators in the

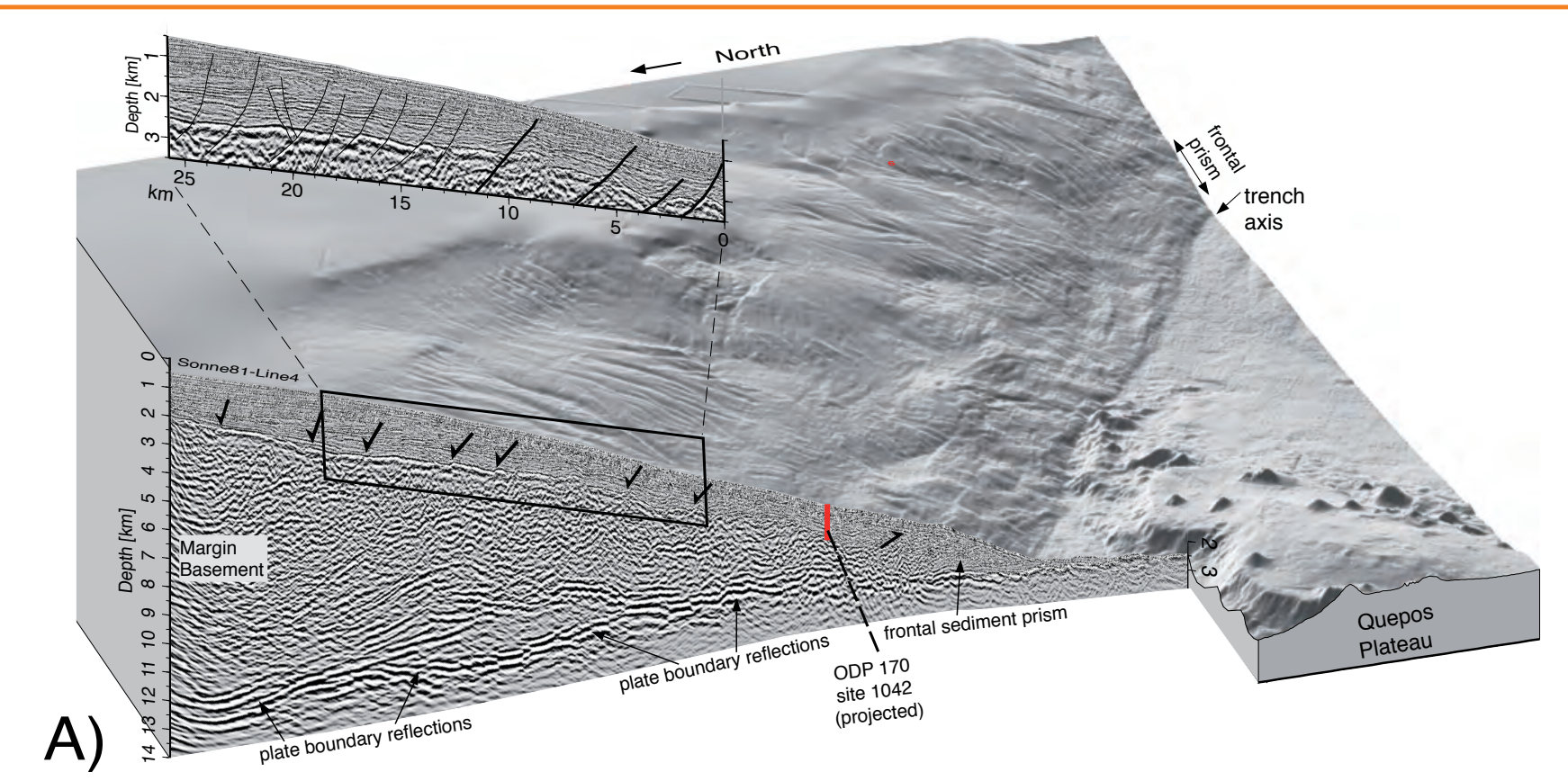

Figure 1. [A] Seismic depth image (pre-stack depth migration) of the Costa Rica margin near the Osa Peninsula (Ranero and von Huene, 2000). Margin basement is formed by igneous rock; major normal faults are emphasized with lines. Inset on the left shows detail of normal faults displacing the top of basement uncorformity and the slope sediment section. Seafloor topography was acquired with multibeam surveying. 


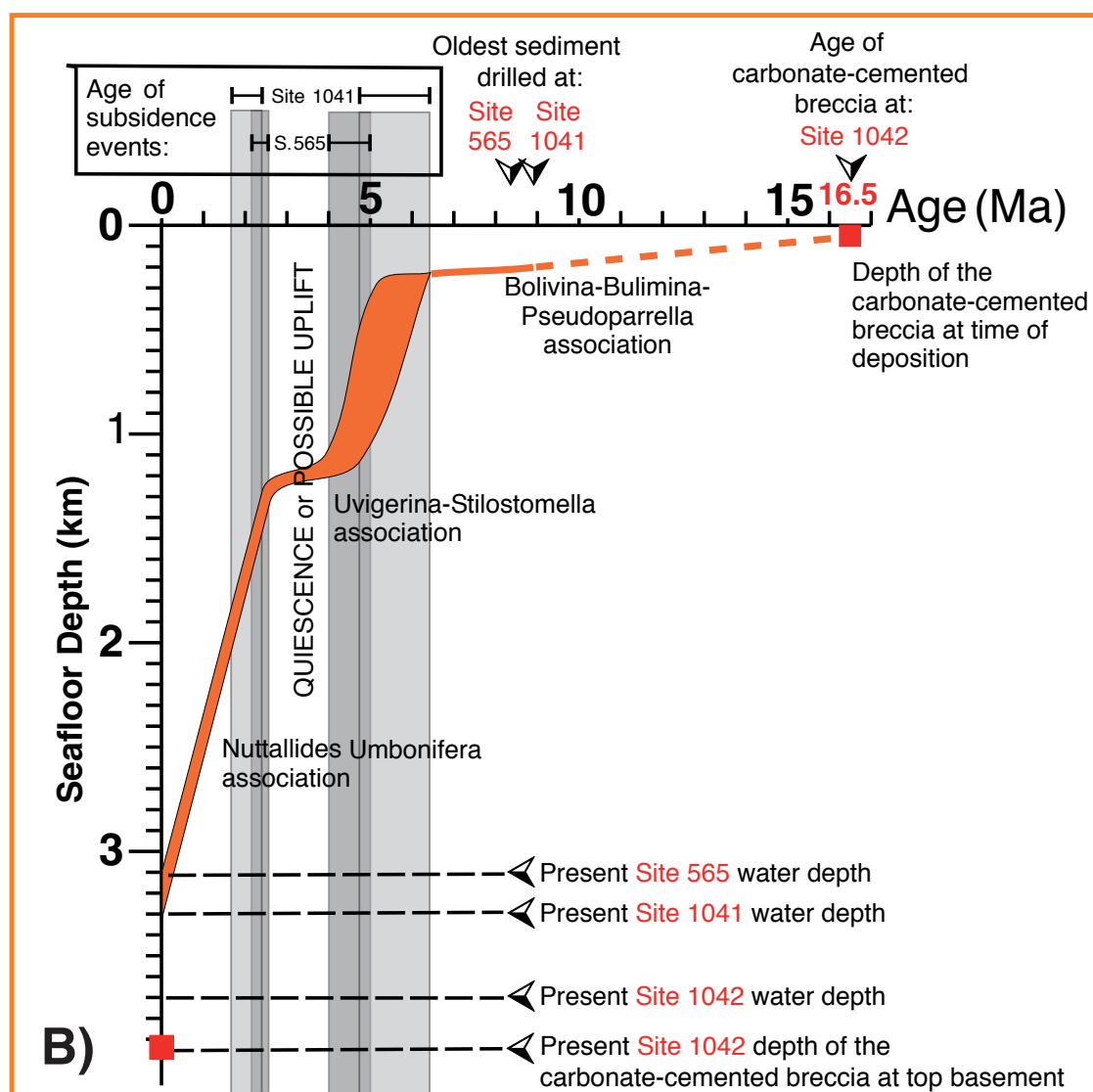

Figure 1. [B] Long-term subsidence history of the Costa Rica margin composed with data from several dril sites offshore the Nicoya Peninsula. Paleodepth information was obtained from studies of benthic foraminifera in the slope sediment, indicating a non-linear subsidence (two main pulses) of about $4 \mathrm{~km}$ for the middle continental slope (Vannucchi et al., 2003).

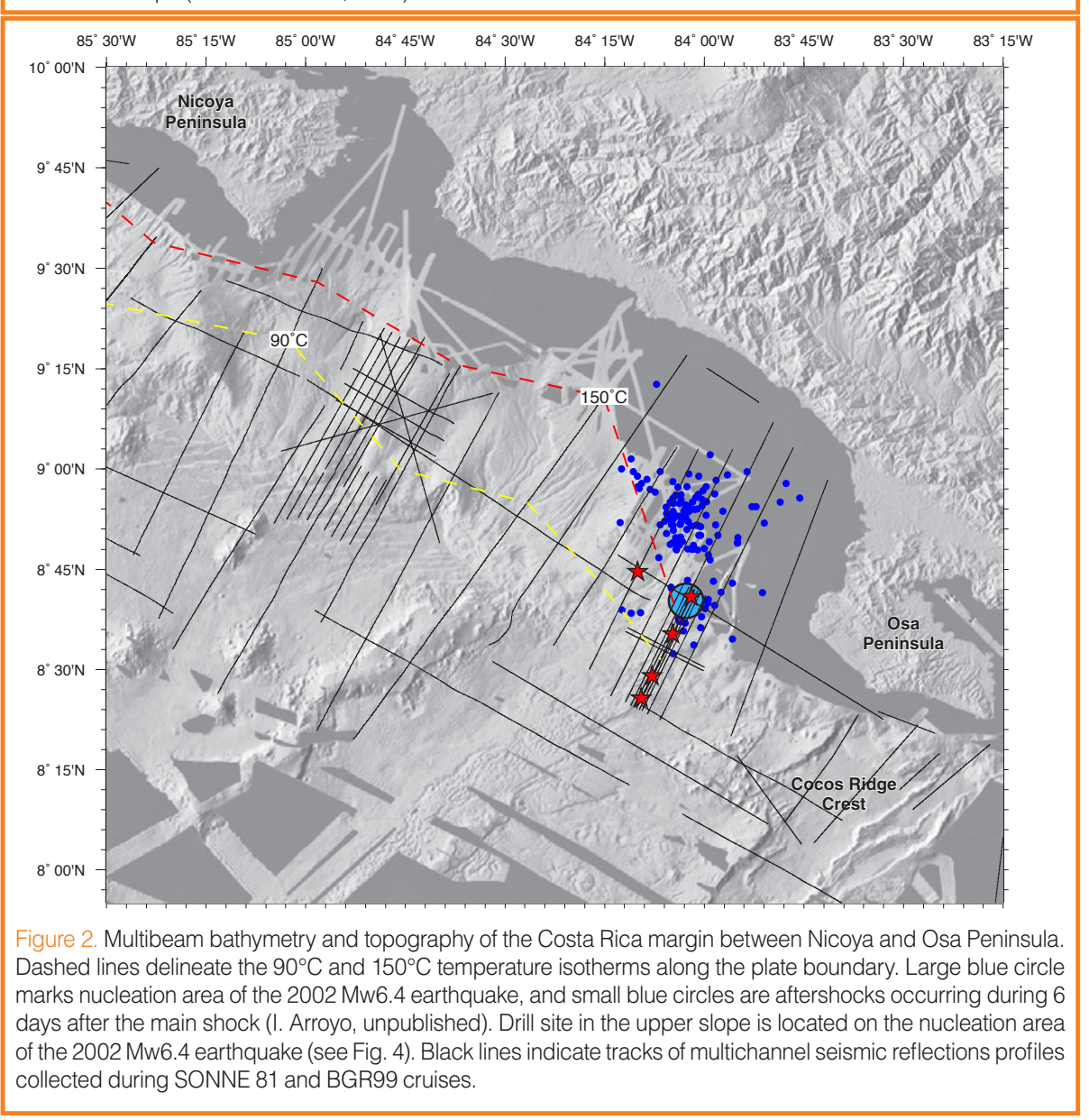

overlying sediment record the progressive margin subsidence since Miocene times (Vannucchi et al., 2004). Subsidence from the surf zone to trench depths requires crustal thinning by erosion of material along the underside of the upper plate.

Drilling on ODP Leg 170 (1996) off Nicoya confirmed that, like Guatemala, the Costa Rican unconformity surface has subsided from shallow water in the past few Myr (Vannucchi et al., 2003) similarly to the neighbor segment off Nicaragua (Ranero et al., 2000). Additionally, the igneous basement subsequently dredged from the lower continental slope of Nicaragua indicated an extension of the continental framework to the trench there. In seismic records the regional unconformity can be followed continuously from the ODP Leg 170 drill transect off Nicoya to the proposed Osa Peninsula drill transect.

Ongoing erosion is indicated by morphology of the slope (Fig. 2). Osa bathymetric high forms the southern flank of a major embayment where erosion and slope retreat are accelerated by subduction of Cocos Ridge and its associated seafloor ridges and seamounts. The regional erosion surface was ground truth during Leg 170 , and the current retreat of the continental slope provides evidence of vigorous tectonic erosion where CRISP drilling is proposed.

Resultsfrom recent work: Researchers in the German SFB 574 (Kiel University) have used high-resolution geophysical tools to map the mounds at a series of mid-slope vent sites. In all, about 125 vent sites were located along $\sim 600 \mathrm{~km}$ of the margin off Costa Rica and Nicaragua, and they seem to be common from Panama to Mexico. Material and fluids were sampled from several mounds, and probe heat flux measurements were collected across a number of sites. Cameras just above the seafloor displayed abundant chemosynthetic carbonates and fauna at the vent sites. 
The mounds are a few hundreds to one thousand meters across with a very hummocky topography. They occur in the area of normal faulting and locally appear at fault scarps. Heat flux over and around the mounds is high compared to the regional background values, indicating venting of deeplysourced fluid (Grevemeyer et al., 2004). Pore fluid chemistry documents low chlorinity fluids, and chemical modeling indicates that they come from dehydration of clays (Hensen et al., 2004). First-order estimates of fluid flow budget across the forearc indicate that most fluid released during dehydration of sediment in the subduction channel traverses the upper plate and is released across the mid-slope vent sites (Ranero et al., 2007). Dehydration of the sediment subducting with the lower plate is proposed as one of the significant causes for the transition to stick-slip behavior and seismogenesis. The massive fluid release across the upper plate of erosional margins is one of the unique processes investigated during CRISP.

Also unique to CRISP is the possibility to drill the nucleation area of the 20 November 2002, Mw6.4 interplate thrust earthquake. The earthquake was recorded on an array of ocean bottom seismometers as well as on the Costa Rican National Seismological Network on land (Fig. 3). The full array provides a database for accurate relocation of the earthquake and its aftershocks (I. Arroyo, in preparation). The main shock is essentially located in the position of the proposed 5-km-deep riser drill hole to the seismogenic zone. Downhole instrumentation, including seismometers, will provide a 3-D seismic image around the drill hole with a radius of several kilometers including the area of the Mw6.4 nucleation. Attribute analysis of the seismic data will permit an estimation of the general physical properties of the upper plate and plate boundary.

CRISP: The shallow dip of the subduction zone off southern Costa Rica and the relatively high temperature of the subducting ocean crust bring materials and processes involved in seismogenesis to depths reachable by drilling with the riser ship Chikyu. CRISP is structured in non-riser (Program A) and riser (Program B) stages that systematically lead from shallow non-riser to deep riser drilling (Fig. 4). Program A provides background information for Program B, which reaches the unstable slip of the seismogenic zone. Program A drilling allows the characterization of lower plate oceanic igneous rock and hydrology before subduction, as well as under the front of the margin. With standard ODP

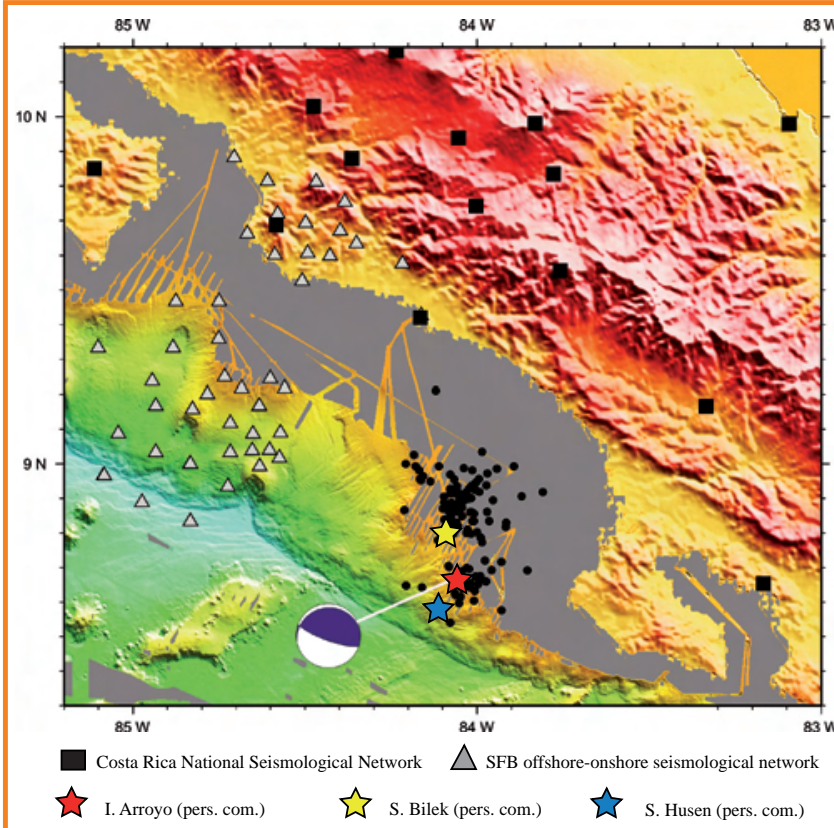

Figure 3. Location of the main shock and aftershocks of the 2002 Mw6.4 earthquake (red star). Triangles indicate the array of ocean bottom seismometers that recorded the quake; black squares are seismographs of the local network. Previous locations without the offshore seismograph array are shown in yellow and blue stars.

drilling technology it also provides the samples to characterize upper plate basement rock. Logging and instrumentation will provide accurate information on the upper plate thermal structure, interplate earthquake nucleation, and rupture propagation, which are key for a successful planning of deeper riser drilling. In Program B, the riser sites locations are constrained with the results from downhole instruments and conventional geophysical experiments, rock mechanics laboratory experiments, and forward modeling. Program B drilling reaches $3 \mathrm{~km}$ below seafloor to sample for the first

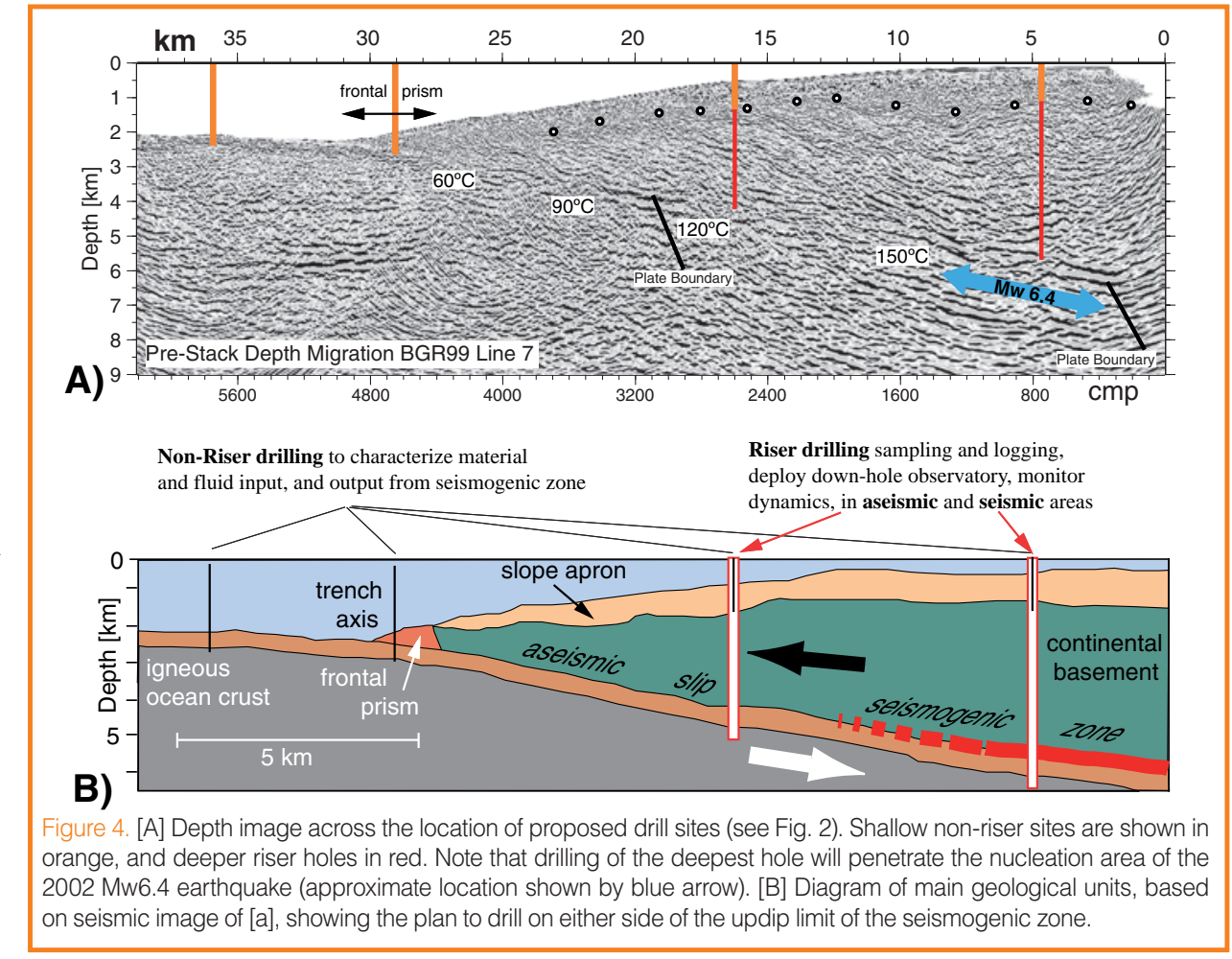


time the subducting eroded debris along the plate interface, in the transition area from stable to stick slip, where temperatures of $\sim 100^{\circ} \mathrm{C}$ occur. Thus, it defines conditions in the zone before the unstable slip and provides the observations to later isolate material transformations, fluid abundance and flow, and dynamic changes causing seismogenesis. Program $\mathrm{B}$ riser drilling is engineered based on results of Program A cores and down hole geophysics. The most recent relocation of the $2002 \mathrm{Mw} 6.4$ earthquake epicenter is at the proposed location of the drill site into the seismogenic zone. Thus, the nucleation area of a large earthquake may be sampled. Riser hole results input to laboratory experiments and modeling can indicate conditions deeper in the seismogenic zone. If found attractive for further work, the results from modeling can be verified in the future with $\sim 7 \mathrm{~km}$ drilling under the auspices of the International Continental Drilling Project at sites on the Osa Peninsula.

With a low sediment supply, fast convergence rate, abundant seismicity, subduction erosion, a shallow plate boundary, and optimal mid-latitude weather conditions, the Middle America Trench offers excellent opportunities to learn causes of earthquake genesis along erosional margins. CRISP is complementary to other seismogenic zone drilling projects (e.g., San Andreas Fault Observatory-SAFOD- and NantroSeize) because it includes studies of earthquake generation in a different setting, one common to about $50 \%$ of all convergent margins worldwide.

\section{Acknowledgements}

We thank Ivonne Arroyo (IfM-GEOMAR) for providing the relocation of the $2002 \mathrm{Mw} 6.4$ thrust event shown in figures 2 and 3 and aftershocks in figure 2 , and for producing figure 3 .

\section{References}

Grevemeyer, I., Kopf, A.J., Fekete, N., Kaul, N., Villinger, H.W., Heesemann, M., Wallmann, K., Spieß, V., Gennerich, H.-H., Müller, M., and Weinrebe, W., 2004. Fluid flow through active mud dome Mound Culebra offshore Nicoya Peninsula, Costa Rica: evidence from heat flow surveying. Marine Geology 207, 145-157, doi:10.1016/j.margeo.2004.04.002.

Hensen, C., Wallmann, K., Schmidt, M., Ranero, C.R., and Suess, E., 2004. Fluid expulsion related to mud extrusion off Costa Rica -a window to the subducting slab. Geology, 32:201-204, doi:10.1130/G20119.1.

Moore, J.C. and Saffer, D.M., 2001. Updip limit of the seismogenic zone beneath the accretionary prism of southwest Japan: An effect of diagenetic to low-grade metamorphic processes and increasing effective stress, Geology, 29:183-186, doi:10.1130/0091-7613(2001)029<0183;ULOTSZ>2.0CO;2.

Ranero, C.R. and von Huene, R., 2000. Subduction erosion along the Middle America convergent margin. Nature, 404:748-752, doi:10.1038/35008046.

Ranero, C.R., von Huene, R., Flueh, E., Duarte, M., and Baca, D., 2000. A cross section of the forearc Sandino Basin, Pacific
Margin of Nicaragua. Tectonics, 19:335-357, doi:10.1029/ 1999TC900045.

Ranero, C., Grevemeyer, I., Sahling, H., Barckhausen, U., Hensen, C., Wallmann, K., Weinrebe, W., Vannucchi, P., von Huene, R., and McIntosh, K., 2007. The hydrogeological system of erosional convergent margins and its influence on tectonics and interplate seismogenesis Geosystems, Geophysics, Geochemistry (in press).

Vannucchi, P., Ranero, C.R., Galeotti, S., Straub, S.M., Scholl, D.W., and McDougall-Ried, K., 2003. Fast rates of subduction erosion along the Costa Rica Pacific margin: implications for non-steady rates of crustal recycling at subduction zones. J. Geophys. Res., 108:2511, doi:10.1029/2002JB002207.

Vannucchi, P., Galeotti, S., Clift, P., Ranero, C.R., and von Huene, R., 2004. Long term subduction erosion along the Middle America Trench offshore Guatemala. Geology, 32:617-620.

von Huene, R., Ranero, C.R., and Vannucchi, P., 2004. A model for subduction erosion. Geology $y_{2}$ 32:913-916; doi: 10.1130/ G20563.1.

\section{Authors}

César R. Ranero, ICREA Research Professor, Instituto de Ciencias del Mar, CMIMA, CSIC, Pg. Maritim de la Barceloneta 37-49, 08003 Barcelona, Spain, e-mail: cranero@ icm.csic.es.

Paola Vannucchi, Department of Scienze della Terra, Università di Firenze, Via La Pira, 4, Italy.

Roland von Huene, Department of Geology, University of California, Davis and Geomar, Kiel, 2910 North Canyon Rd., Camino, Calif. 95709, U.S.A.

and the CRISP proponents: Guillermo E. Alvarado, Udo Barckhausen, Peter Baumgartner, Susan Bilek, Peter Clift, Philippe Charvis, Jean-Yves Collot, Heather DeShon, Tim Dixon, Giulio Di Toro, LeRoy Dorman, Donald M. Fisher, Simone Galeotti, Ingo Grevemeyer, Robert Harris, Kaj Hoernle, Stephan Husen, Miriam Kastner, Gaku Kimura, Masataka Kinoshita, Serge Lallemand, Alex J. Maltman, Chris Marone, Takeshi Matsumoto, Kirk McIntosh, Christian Mueller, Soenke Neben, Lisa Patino, Adina Paytan, Jason Phipps Morgan, Marino J. Protti, Christian Reichert, Sanny Saito, Dave Scholl, Susan Schwartz, Glen Snyder, Eli Silver, Volkhard Spiess, Erwin Suess, Heiner Villinger, Sergio Vinciguerra, Klaus Wallmann. 